\title{
Hyperinsulinaemia, supplemental protein and branched-chain amino acids when combined can increase milk protein yield in lactating sows
}

\author{
Frank R. Dunshea ${ }^{1}$, Dale E. Bauman ${ }^{2}$, Elizabeth A. Nugent ${ }^{1}$, Douglas J. Kerton ${ }^{1}$, Raymond H. King ${ }^{1}$ \\ and Ian McCauley ${ }^{1}$ \\ ${ }^{1}$ Department of Primary Industries, 600 Sneydes Road, Werribee, Victoria, Australia, 3030 \\ ${ }^{2}$ Department of Animal Science, Cornell University, Ithaca, NY14853, USA
}

(Received 29 February 2004 - Revised 1 October 2004 - Accepted 1 November 2004)

\begin{abstract}
The aim of this study was to determine whether dietary supplementation with branched-chain amino acids, and the infusion of insulin and dextrose, would increase milk protein secretion in the sow. The experiment involved sixteen lactating sows fed either a normal lactation diet (162 $\mathrm{g} / \mathrm{kg}$ crude protein, $n$ 8) or a high-protein diet $(230 \mathrm{~g} / \mathrm{kg}$ crude protein, $n 8)$ supplemented with branched-chain amino acids (valine, isoleucine and leucine). Sows were either infused with insulin and dextrose or not infused at all during mid (day 5-10) and late (day 17-22) lactation in a single reversal design. Blood samples were analysed for glucose, and the dextrose infusion rate was adjusted to maintain the blood glucose level within $15 \%$ of pre-infusion levels. Milk (10.1 $v$. $11 \cdot 1 \mathrm{~kg} / \mathrm{d}$; $P=0.014)$ and lactose $(628 v .727 \mathrm{~g} / \mathrm{d} ; P=0.002)$ yield increased with insulin infusion, whereas milk protein content $(5.0 \% \quad v$. $5.5 \%$; $P=0.007)$ was increased in diets supplemented with protein and branched-chain amino acids. Piglet growth was increased by feeding the higher-protein diet (237 v. $273 \mathrm{~g} / \mathrm{d} ; P=0.05)$ but not significantly increased by insulin infusion $(245 v .265 \mathrm{~g} / \mathrm{d} ; P=0 \cdot 11)$. These effects were additive such that the combined treatment resulted in a $24 \%(56 \mathrm{~g} / \mathrm{d} ; P<0.05)$ increase in piglet growth rate. These data demonstrate that increasing the dietary protein/branched-chain amino acid content can increase milk protein secretion but not milk yield. The infusion of insulin and dextrose increased milk and milk lactose yields, and tended to increase milk protein yield but not milk protein content. These effects are additive and translate to increased protein yield and piglet growth.
\end{abstract}

Pig: Lactation: Insulin: Branched-chain amino acids: Protein

The pig has evolved to have a high fat content in its milk compared with that of other domesticated animals, to aid the survival of piglets born with very little insulation or energy reserves (Mellor \& Cockburn, 1986). Today, however, pigs are kept in more controlled settings and do not require milk with such a high fat (relative to protein) content after the first few days of life. Indeed, such a milk may be a serious constraint to piglet growth performance. The protein requirement of artificially reared pigs of between 2 and $7 \mathrm{~kg}$ is $10.7-11.5 \mathrm{~g} / \mathrm{MJ}$ (Williams, 1976; Auldist et al. 1997), whereas the protein content of sow's milk is less than 8.0 g/MJ (King et al. 1993b). Therefore, if the milk protein content of sow's milk can be increased without necessarily changing milk yield, sucking pig growth can be increased by up to $40 \%$. This is particularly important during late lactation when milk yield is generally insufficient to maintain piglet growth rate (Dunshea, 2003). For example, sow milk production increases over the first 2 weeks of lactation before reaching a plateau (Toner et al. 1996), and thus the extent to which milk yield limits piglet growth rate is exacerbated as lactation advances (Dunshea, 2003).

McGuire et al. (1995) demonstrated that the simultaneous infusion of insulin and dextrose increased milk protein content and yield by $7 \%$ and $3.5 \%$, respectively, in dairy cows. Interestingly, the circulating concentrations of amino acids, in particular the branched-chain amino acids (BCAA), were markedly decreased, presumably because they were preferentially taken up and utilised by the mammary gland through either oxidation or incorporation into milk proteins. In a subsequent study in which additional protein was supplied as an abomasal infusion of casein, it was found that whereas casein and insulin/dextrose increased milk protein yield by $10 \%$ and $4 \%$, respectively, the combined treatment increased milk protein yield by $28 \%$ (Griinari et al. 1997). In this context, the amino acid profile and ileal digestibility of casein, including the BCAA, is similar to that of whole-milk protein (Rutherfurd \& Moughan, 1998), whereas the relative proportions of BCAA are in excess of those in muscle and other tissues (Reeds \& Mersmann, 1991). Despite supplying additional protein as casein, the infusion of insulin and dextrose decreased the plasma concentrations of the BCAA valine, isoleucine and leucine by approximately $60 \%$ while the plasma concentrations of the other essential amino acids decreased by an average of $25 \%$ (range $13-40 \%$ ). It is therefore possible that supplying additional BCAA may stimulate milk protein yield even further if the depression in BCAA can be avoided. The following study was thus conducted to determine whether insulin and dextrose infusion, and supplemental protein and BCAA, could increase milk yield and piglet growth. 


\section{Materials and methods}

\section{Experimental design and methodology}

All procedures involving animals were approved by the Victorian Institute of Animal Science Animal Ethics Committee. Sixteen cross-bred (Large White $\times$ Landrace) multiparous sows nursing litters of eleven piglets were maintained in farrowing crates throughout the study. Sows were catheterised on the morning of day 4 of lactation after having their feed removed for $12 \mathrm{~h}$. Muscle relaxation was induced with an intramuscular injection of azoperone (Stresnil, $40 \mathrm{mg} / \mathrm{ml}$; Boehringer, North Ryde, New South Wales, Australia), after which anaesthesia was induced and maintained with halothane (Fluothane; Orica, Ascot Vale, Victoria, Australia). Two silastic catheters (Sil-Med Corporation, Taunton MA, USA; $0.16 \mathrm{~mm}$ internal diameter, $0.32 \mathrm{~mm}$ external diameter) were inserted $15 \mathrm{~cm}$ into the anterior vena cava via each of the cephalic veins (Dunshea \& King, 1995). The catheters were exteriorised in the region of the interscapular space on the back of the animals and stored in a cloth pocket glued to the back. After catheterisation, sows were given a $4 \mathrm{~d}$ course of broad-spectrum antibiotic (Terramycin/LA, oxytetracycline $200 \mathrm{mg} / \mathrm{ml}$; Pfizer, West Ryde, New South Wales, Australia) and exit wounds were treated with antibiotic powder (Terramycin, oxytetracycline, $20 \mathrm{mg} / \mathrm{g}$; Pfizer). Catheters were flushed daily with physiological saline containing $\mathrm{K}_{2}$ EDTA $(12.5 \mathrm{~g} / \mathrm{l})$.

Sows were randomly allocated to either a conventional lactation ration $(162 \mathrm{~g} / \mathrm{kg}$ crude protein $(\mathrm{CP}))$ or a high-protein diet $(230 \mathrm{~g} / \mathrm{kg} \mathrm{CP})$ with supplemental free BCAA (valine, isoleucine and leucine) for the duration of lactation (Table 1). Sows were offered $3.0 \mathrm{~kg}$ of their respective diet on the first day of lactation, and the daily allocation was increased by $0.5 \mathrm{~kg}$ increments until ad libitum intakes were achieved. Commencing on day 10 of lactation, half the sows were bled at $08.00 \mathrm{~h}$ every day for $5 \mathrm{~d}$,

Table 1. Experimental diets $(\mathrm{g} / \mathrm{kg})$

\begin{tabular}{|c|c|c|}
\hline & Control & High protein/BCAA \\
\hline \multicolumn{3}{|l|}{ Ingredient } \\
\hline Wheat (11\% CP) & 635.5 & $544 \cdot 3$ \\
\hline Wheat bran & $100 \cdot 0$ & $100 \cdot 0$ \\
\hline Soyabean meal ( $48 \% \mathrm{CP})$ & $91 \cdot 0$ & $81 \cdot 1$ \\
\hline Fish meal $(65 \% \mathrm{CP})$ & $30 \cdot 7$ & $50 \cdot 0$ \\
\hline Blood meal (83\% CP) & $6 \cdot 3$ & $40 \cdot 0$ \\
\hline Tallow & $29 \cdot 0$ & $14 \cdot 8$ \\
\hline Limestone & $6 \cdot 8$ & $10 \cdot 0$ \\
\hline Dicalcium phosphate & $17 \cdot 3$ & $19 \cdot 1$ \\
\hline Salt & $2 \cdot 0$ & $2 \cdot 0$ \\
\hline Vitamins and mineral premix & $2 \cdot 0$ & $2 \cdot 0$ \\
\hline Skim milk powder & $70 \cdot 0$ & $120 \cdot 0$ \\
\hline Lysine & 4.57 & 1.63 \\
\hline Methionine & $1 \cdot 78$ & $2 \cdot 13$ \\
\hline Threonine & $1 \cdot 78$ & 0.73 \\
\hline Valine & 1.38 & $5 \cdot 28$ \\
\hline Isoleucine & & 3.45 \\
\hline Leucine & & 3.42 \\
\hline \multicolumn{3}{|l|}{ Estimated composition } \\
\hline Digestible energy (MJ/kg) & $14 \cdot 5$ & $14 \cdot 5$ \\
\hline Crude protein & 162 & 230 \\
\hline Available lysine & $9 \cdot 6$ & $12 \cdot 8$ \\
\hline Available valine & $7 \cdot 70$ & $15 \cdot 5$ \\
\hline Available isoleucine & $5 \cdot 30$ & $10 \cdot 6$ \\
\hline Available leucine & $9 \cdot 80$ & $20 \cdot 0$ \\
\hline Total available BCAA:lysine $(\mathrm{g}: \mathrm{g})$ & $2 \cdot 37$ & 3.60 \\
\hline
\end{tabular}

BCAA, branched-chain amino acid; CP, crude protein. and the blood was rapidly analysed with a blood glucose monitor to determine blood glucose concentrations. The other half of the sows were bled every $30 \mathrm{~min}$ for $2 \mathrm{~h}$ from $08.00 \mathrm{~h}$, and the blood was rapidly analysed with a blood glucose monitor to determine baseline blood glucose concentrations.

Commencing at $10.00 \mathrm{~h}$ on day 10 , the latter half of the sows were infused with insulin ( $11 \mathrm{mU} / \mathrm{kg}$ per $\mathrm{h})$ and sufficient dextrose (50\% dextrose) to maintain euglycyaemia for $5 \mathrm{~d}$. The dose of insulin was chosen as the maximum dose that did not reduce feed intake in a preliminary study (see discussion). To achieve euglycaemic conditions, venous blood samples were obtained every $2 \mathrm{~h}$ for the first $2 \mathrm{~d}$ and rapidly analysed for glucose concentrations, and the dextrose infusion rate was adjusted to maintain blood glucose within $15 \%$ of the pre-infusion levels. After $2 \mathrm{~d}$, blood glucose was measured at least every $8 \mathrm{~h}$, and infusion rates were adjusted only if glycaemia fluctuated dramatically. Milk yield was determined by ${ }^{2} \mathrm{H}_{2} \mathrm{O}$ dilution between days 1 and 5 of infusion (Prawirodigdo et al. 1990) and milk samples were obtained on days 3 and 5 to determine milk composition.

After nursing at approximately $09.00 \mathrm{~h}$ on day 1 , the piglets were separated from the dam for $45 \mathrm{~min}$ to standardise gut fill and were weighed. Each piglet was then injected with a weighed dose of ${ }^{2} \mathrm{H}_{2} \mathrm{O}(2.0 \mathrm{~g} / \mathrm{kg}$ live weight). At $1 \mathrm{~h}$ after injection, a $5 \mathrm{ml}$ blood sample was obtained via vena cava puncture in order to determine the equlibration concentration of ${ }^{2} \mathrm{H}_{2} \mathrm{O}$ in the body fluid. After nursing at approximately $09.00 \mathrm{~h}$ on day 5 of the treatment period, the pigs were separated from the dam for $45 \mathrm{~min}$ and another $5 \mathrm{ml}$ blood sample was obtained. The concentration of ${ }^{2} \mathrm{H}_{2} \mathrm{O}$ in the plasma was determined using Fourier transforminfrared spectrometry, as described by Glencross et al. (1997). Since milk was the only source of water consumed by the piglets, the milk yieid of the sows was calculated from the water turnover of the piglets, as described previously (Prawirodigdo et al. 1990; King et al. 1993b).

Milk samples $(5-10 \mathrm{ml}$ per gland) were collected from three medial glands during a suckling bout intitiated by the piglets (i.e. without the use of oxytocin). Plasma samples were obtained for insulin, glucose, amino acids and non-esterified fatty acids (NEFA). Infusions commenced on day 10 and continued until day 15 . Sows that had not received the hyperinsulinaemiceuglycaemic clamp earlier received the insulin/dextrose infusion from day 17 to 22, and milk yield and composition were determined as above. Milk yield was determined as before, with the exception that a blood sample was taken before ${ }^{2} \mathrm{H}_{2} \mathrm{O}$ injection to determine residual ${ }^{2} \mathrm{H}_{2} \mathrm{O}$.

\section{Chemical analyses}

During the hyperinsulinaemic-euglycaemic clamp, blood glucose concentrations were monitored using a blood glucose monitor and strips (Accucheck; Roche, Mannheim, Germany). Plasma was analysed for insulin, glucose and NEFA using kit assays validated in our laboratory (Ostrowska et al. 2002). Inter- and intra-assay variations were $9.2 \%$ and $6.1 \%, 2.9 \%$ and $1.6 \%$, and $5.8 \%$ and $4.8 \%$ for insulin, glucose and NEFA, respectively. Plasma and milk amino acids were analysed by ion-exchange chromatography (Rayner, 1985; King et al. 1993a). Milk samples were prepared for amino acid analyses by freeze-drying, followed by fat extraction with a mixture of chloroform and acetate. The fatfree sample was air-dried and ground using a mortar and pestle, and then passed through a $0.5 \mathrm{~mm}$ sieve prior to analyses (King 
et al. 1993b). Milk protein, lactose and fat were analysed in whole liquid milk as described by Atwood \& Hartmann (1992). Ash was assumed to be $8.8 \mathrm{~g} / \mathrm{kg}$, and total solids were estimated by the sum of ash, protein, lactose and fat (King et al. 1993b).

\section{Statistics}

Growth and plasma constituent data were analysed by ANOVA with the main effects being insulin infusion, stage of lactation and diet. Blocking structure was sow. Growth rate was measured between days 1 and 5 of each infusion, whereas the ANOVA for blood and plasma constituents was conducted using the pooled average of the samples obtained at $08.00 \mathrm{~h}$ on each day for each sow.

\section{Results}

Basal blood glucose was not affected by dietary protein content (4.04 v. $3.99 \mathrm{mmol} / 1 ; P=0.68)$, and the simultaneous infusion of dextrose ensured that euglycaemia was maintained during the insulin infusion $(4.02$ v. $4.01 \mathrm{mmol} / \mathrm{l} ; P=0.97$; Fig. 1). There was no effect of dietary protein on basal insulin concentrations $(27.2$ v. $24.5 \mathrm{mU} / \mathrm{l} ; P=0.52)$, whereas insulin infusion at a rate of $11 \mathrm{mU} / \mathrm{kg}$ per $\mathrm{h}$ increased pre-feeding plasma insulin concentrations by approximately $50 \%(21.1$ v. $31.4 \mathrm{mU} / \mathrm{l} ; P=0.018$; Fig. 2). The amount of dextrose required to maintain euglycaemia was lower in sows fed the high-protein diet supplemented with BCAA (3.91 v. $2.80 \mathrm{mmol} / \mathrm{min} ; P<0.001 ;$ Fig. 1) and was

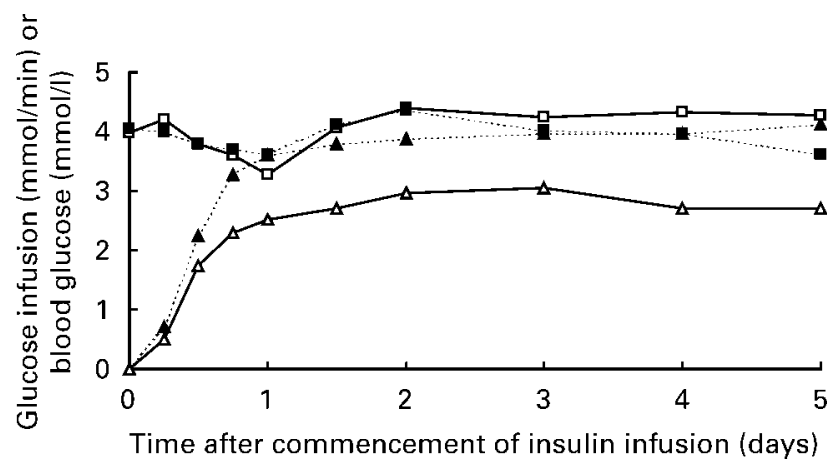

Fig. 1. Effect of basal (closed symbols) or high-protein + branched-chain amino acids (open symbols) on blood glucose $(\square, \boldsymbol{\square})$ or the dextrose infusion rate $(\triangle, \Delta)$ required to maintain glycaemia during insulin infusion $(11 \mathrm{mU} / \mathrm{kg}$ per $h$ ) in sows. SED (for diet $\times$ insulin $\times$ day) for glucose infusion rate and blood glucose was $1.2 \mathrm{mmol} / \mathrm{min}$ and $0.46 \mathrm{mmol} / \mathrm{l}$, respectively.

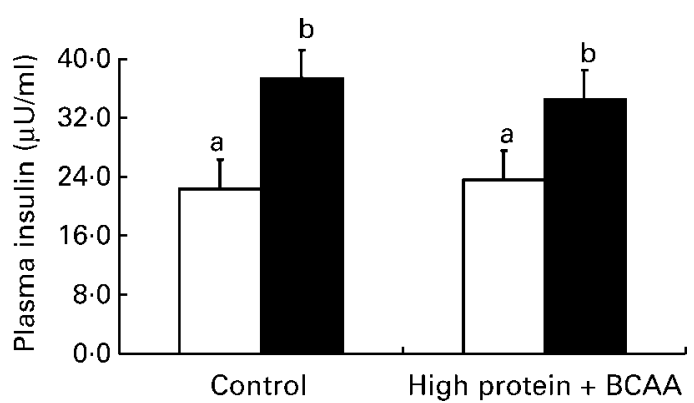

Fig. 2. Effect of control or high-protein + branched-chain amino acid (BCAA) lactation diets under basal conditions $(\square)$ gross energy or during a simultaneous insulin and glucose infusion ( $\square$ ) on plasma insulin. Values are means and SED for diet $\times$ insulin. Values with different letters are significantly different $(P<0.05)$ higher during mid compared with late lactation (2.94 v. $3.76 \mathrm{mmol} / \mathrm{min} ; P=0.005)$. There was, however, a significant interaction $(P<0.001)$ such that the amount of dextrose infused was lower in sows fed the high-protein diet supplemented with BCAA during mid lactation $(4.15$ v. $2.06 \mathrm{mmol} / \mathrm{min})$ but not during late lactation $(3.67$ v. $3.85 \mathrm{mmol} / \mathrm{min})$.

Piglet growth was increased by feeding the higher-protein diet supplemented with BCAA (237 v. $273 \mathrm{~g} / \mathrm{d} ; P=0.051)$ but not significantly increased by insulin infusion $(245$ v. $265 \mathrm{~g} / \mathrm{d} ; P=0 \cdot 11)$. The effects were, however, additive such that the combination of the high-protein + BCAA diet and hyperinsulinaemia resulted in a $24 \%(229$ v. $285 \mathrm{~g} / \mathrm{d} ; P<0.01)$ increase in piglet growth rate (Fig. 3). Litter growth was increased by feeding the higher-protein diet $(2.60 v .2 .91 \mathrm{~kg} / \mathrm{d} ; P=0.044)$ but not significantly increased by insulin infusion $(2.66 v .2 .85 \mathrm{~kg} / \mathrm{d} ; P=0.15)$. Again, however, effects were additive such that the combined treatment resulted in a $20 \%(2.52$ v. $3.03 \mathrm{~kg} / \mathrm{d} ; P<0.01)$ increase in litter growth rate.

Milk yield was not altered by dietary protein $(10.7 v .10 .5 \mathrm{~kg} / \mathrm{d}$; $P=0.92)$, whereas it was increased during insulin infusion $(10.1 \mathrm{v}$. $11.1 \mathrm{~kg} / \mathrm{d} ; P=0.014$; Table 2). Milk protein content was increased by feeding additional protein and BCAA $(5 \cdot 0$ v. $5.5 \% ; P=0.007)$ but was not altered during insulin infusion $(5 \cdot 3$ v. $5 \cdot 1 \% ; P=0 \cdot 29)$. Milk protein output was not significantly changed by dietary protein and BCAA (530 v. $574 \mathrm{~g} / \mathrm{d} ; P=0 \cdot 24)$, although an increase of similar magnitude during insulin infusion approached statistical significance (534 v. $571 \mathrm{~g} / \mathrm{d} ; P=0.099)$. Effects were additive such that the combined treatment resulted in a $16 \%$ (523 v. $605 \mathrm{~g} / \mathrm{d} ; P<0 \cdot 01)$ increase in milk protein output.

Milk fat content was neither changed by dietary protein $(6.9 \mathrm{v}$. $6.8 \% ; P=0.91)$ nor significantly altered during the insulin infusion $(7.3$ v. $6.3 \% ; P=0.13)$. Milk fat output was not altered by dietary protein $(732 v .718 \mathrm{~g} / \mathrm{d} ; P=0.89)$ or insulin infusion (738 v. $711 \mathrm{~g} / \mathrm{d} ; P=0.75)$. Milk lactose content was neither changed by dietary protein $(6.4 v .6 .4 \% ; P=0.80)$ nor significantly altered during insulin infusion $(6.3$ v. $6.5 \% ; P=0.14)$. Milk lactose output was not altered by dietary protein $(684 v .671 \mathrm{~g} / \mathrm{d}$; $P=0.81)$ but was markedly increased during insulin infusion $(628 v .727 \mathrm{~g} / \mathrm{d} ; P=0.002)$ due to a combination of both increased milk yield and a non-significant increase in milk lactose content. The ratio of protein:energy in milk was not significantly increased by dietary protein $(10.2$ v. $10.9 \mathrm{~g} / \mathrm{MJ}$ gross energy; $P=0.11)$ and was unchanged during insulin infusion $(10.4 v \cdot 10 \cdot 7 \mathrm{~g} / \mathrm{MJ}$ gross energy; $P=0.57$ ).

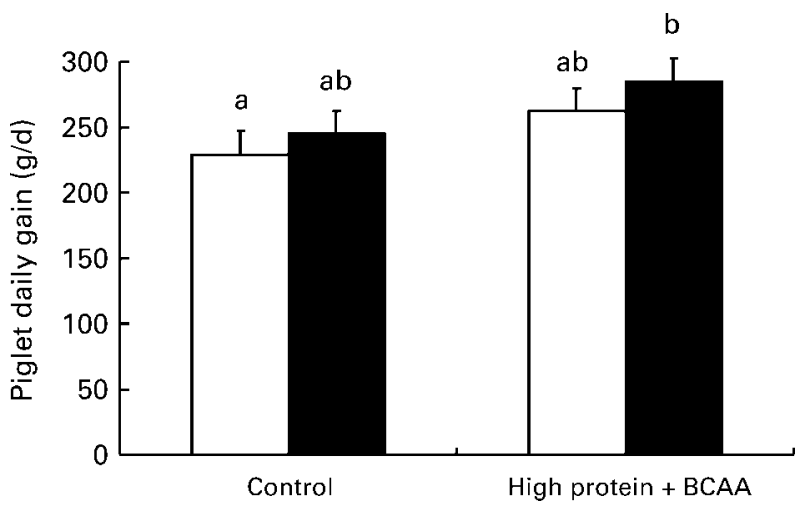

Fig. 3. Effect of control or high protein + branched-chain amino acid (BCAA) lactation diets under basal conditions $(\square)$ or during a simultaneous insulin and glucose infusion $(\boldsymbol{\square})$ on piglet daily gain. Values are means and SED for diet $X$ insulin. Values with different letters are significantly different $(P<0.05)$. 


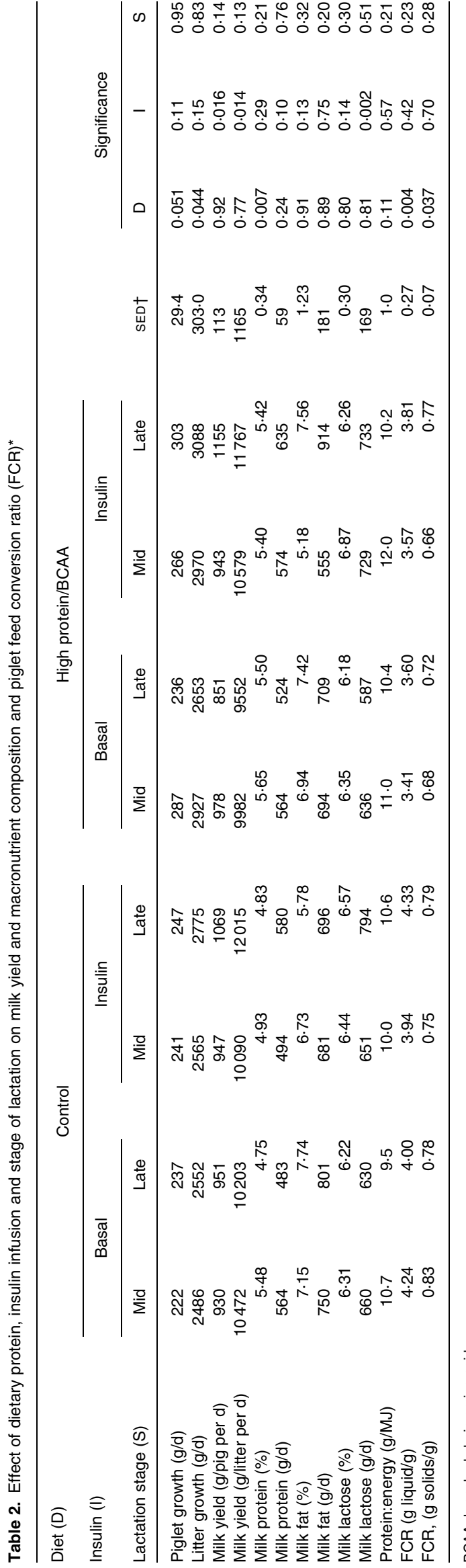

The feed conversion rate (FCR) of liquid sow milk decreased by feeding supplemental protein $(4.13$ v. $3.60 ; P=0.004)$ but was unchanged during insulin infusion $(3.81$ v. $3.91 ; P=0.42)$. Likewise, the FCR of sow milk solids decreased by feeding supplemental protein $(0.79$ v. $0.71 ; P=0.037)$ but was unchanged during insulin infusion $(0.75$ v. $0.74 ; P=0.70)$. There were no major differences in macronutrient content or yields or the FCR of milk between mid and late lactation (Table 2).

The effects of dietary protein combined with supplemental BCAA and the hyperinsulinaemic-euglycaemic clamp on the amino acid composition of sow's milk are shown in Table 3. Increasing the dietary protein, combined with BCAA fortification, increased the content of many of the amino acids in milk, including alanine, aspartic acid, isoleucine, leucine, lysine, methionine, phenylalanine, serine, threonine, tyrosine and valine. On the other hand, the milk content of arginine, glutamic acid, glycine and proline was relatively unaffected by dietary protein. Insulin and glucose infusion failed to alter the amino acid content of sow's milk (Table 3).

The output of valine in sow milk tended to be increased by feeding the higher-protein diet $(30.8 v .38 .3 \mathrm{~g} / \mathrm{d} ; P=0.089)$ and by insulin infusion $(31.6 v .37 .5 ; P=0.060)$. These effects were additive such that the combined treatment resulted in a $48 \%$ increase in milk valine output (Fig. 4). The output of leucine in sow's milk tended to be increased by feeding the higher-protein $\operatorname{diet}(61.8 v .71 \cdot 1 \mathrm{~g} / \mathrm{d} ; P=0.10)$ and by insulin infusion $(62.5 v$. $70.4 \mathrm{~g} / \mathrm{d} ; P=0.054)$. These effects were additive such that the combined treatment resulted in a $30 \%$ increase in milk leucine output (Fig. 4). The responses to the other BCAA, isoleucine, were qualitatively similar, although the differences were not as great and were not significant $(P>0 \cdot 10$; Fig. 4$)$.

Sow feed intake was not altered by dietary protein $(6.4 v$. $6.7 \mathrm{~kg} / \mathrm{d}, P=0.68)$ or insulin infusion $(6.8 v .6 .3 \mathrm{~kg}, P=0.37)$ but tended to be higher during late lactation $(7.0 v .6 \cdot 1 \mathrm{~kg}$, $P=0.089)$. There was no effect of diet on plasma NEFA concentrations (261 v. $242 \mu \mathrm{mol} / 1 ; P=0.61$ ), whereas insulin infusion decreased plasma NEFA (330 v. $173 \mu \mathrm{mol} / 1 ; P<0.001)$. There was, however, an interaction $(P=0.018)$ between diet and insulin infusion such that plasma NEFA concentrations were higher and fell further during hyperinsulinaemia in sows eating the conventional diet (380 v. $142 \mu \mathrm{mol} / \mathrm{l})$ compared with sows consuming the high-protein diet and supplemented BCAA diet (281 v. $204 \mu \mathrm{mol} / \mathrm{l})$. The stage of lactation had no effect on plasma NEFA concentrations $(P=0.64)$.

Increasing the dietary protein combined with BCAA fortification increased the plasma amino acid concentration of many amino acids, including alanine, arginine, glutamic acid, glutamine, glycine, isoleucine, leucine, lysine, methionine, ornithine, phenylalanine, tyrosine and valine (Table 4). On the other hand, the plasma concentrations of aspartic acid, citrulline, histidine, serine, taurine and threonine were relatively unaffected by dietary protein. Insulin and glucose infusion decreased the plasma concentrations of a few key amino acids, including isoleucine $(-6 \%)$, leucine $(-10 \%)$, methionine $(-11 \%)$, threonine $(-9 \%)$ and tyrosine $(-11 \%)$, although the magnitude of these decreases was relatively small (Table 4 ). The plasma concentrations of all amino acids were higher during late lactation compared with mid lactation, most differences being significant $(P<0 \cdot 05)$. There were also a number of two- and three-way interactions, although the magnitude of these was generally small. 
Table 3. Effect of dietary protein, insulin infusion and stage of lactation on milk amino acid concentrations $(\mathrm{g} / \mathrm{kg})^{*}$

\begin{tabular}{|c|c|c|c|c|c|c|c|c|c|c|c|c|}
\hline \multirow{2}{*}{$\begin{array}{l}\text { Diet (D) } \\
\text { Insulin (I) } \\
\text { Lactation stage (S) }\end{array}$} & \multicolumn{4}{|c|}{ Control } & \multicolumn{4}{|c|}{ High protein/BCAA } & \multirow{2}{*}{ SED $†$} & \multirow{2}{*}{\multicolumn{3}{|c|}{ Significance }} \\
\hline & \multicolumn{2}{|c|}{ Basal } & \multicolumn{2}{|c|}{ Insulin } & \multicolumn{2}{|c|}{ Basal } & \multicolumn{2}{|c|}{ Insulin } & & & & \\
\hline Alanine & $2 \cdot 14$ & 1.61 & 1.99 & 1.85 & $2 \cdot 33$ & $2 \cdot 03$ & $2 \cdot 20$ & $2 \cdot 21$ & 0.24 & 0.023 & 0.79 & 0.084 \\
\hline Arginine & 2.94 & $2 \cdot 32$ & 2.51 & $2 \cdot 42$ & 2.96 & 2.54 & $2 \cdot 75$ & $2 \cdot 78$ & 0.34 & 0.22 & $0 \cdot 70$ & 0.16 \\
\hline Aspartic acid & $6 \cdot 30$ & $4 \cdot 34$ & 5.43 & 5.07 & $6 \cdot 62$ & $5 \cdot 60$ & $6 \cdot 13$ & $6 \cdot 28$ & 0.83 & 0.031 & 0.98 & 0.11 \\
\hline Glycine & 2.03 & $1 \cdot 73$ & 1.91 & 1.69 & 1.98 & $1 \cdot 71$ & $1 \cdot 71$ & 1.94 & 0.20 & 0.95 & 0.68 & 0.23 \\
\hline Histidine & 1.52 & $1 \cdot 11$ & 1.43 & $1 \cdot 22$ & 1.48 & 1.33 & 1.53 & 1.40 & 0.18 & 0.21 & 0.71 & 0.036 \\
\hline Isoleucine & $2 \cdot 70$ & 2.02 & 2.51 & $2 \cdot 26$ & $2 \cdot 83$ & 2.55 & $2 \cdot 77$ & 2.68 & 0.30 & 0.018 & 0.87 & 0.079 \\
\hline Leucine & 6.53 & $4 \cdot 78$ & $6 \cdot 18$ & $5 \cdot 71$ & $7 \cdot 03$ & $6 \cdot 51$ & 6.99 & $6 \cdot 62$ & 0.63 & 0.002 & 0.66 & 0.057 \\
\hline Lysine & $5 \cdot 65$ & $3 \cdot 76$ & $5 \cdot 05$ & 4.53 & $5 \cdot 91$ & $5 \cdot 28$ & $5 \cdot 71$ & $5 \cdot 48$ & 0.71 & 0.022 & 0.91 & 0.056 \\
\hline Methionine & $1 \cdot 16$ & 0.82 & 1.06 & 0.95 & $1 \cdot 17$ & 1.05 & $1 \cdot 15$ & 1.08 & 0.24 & 0.066 & 0.85 & 0.024 \\
\hline Phenylalanine & $2 \cdot 45$ & 1.85 & $2 \cdot 33$ & 2.05 & $2 \cdot 52$ & $2 \cdot 26$ & $2 \cdot 44$ & 2.43 & 0.26 & 0.054 & 0.76 & 0.068 \\
\hline Proline & $6 \cdot 11$ & $5 \cdot 72$ & 6.98 & 5.45 & $6 \cdot 35$ & $5 \cdot 76$ & 5.95 & $6 \cdot 18$ & 0.60 & 0.99 & 0.62 & 0.093 \\
\hline Threonine $\ddagger$ & $2 \cdot 72$ & 1.93 & 2.37 & $2 \cdot 25$ & $2 \cdot 78$ & 2.43 & $2 \cdot 62$ & 2.66 & 0.56 & 0.016 & 0.96 & 0.077 \\
\hline Tyrosine & $2 \cdot 49$ & 1.93 & $2 \cdot 35$ & $2 \cdot 11$ & $2 \cdot 61$ & 2.44 & 2.59 & 2.40 & 0.28 & 0.029 & 0.97 & 0.10 \\
\hline Valine & $2 \cdot 60$ & 2.63 & 3.30 & 2.98 & 3.91 & 3.39 & 3.72 & 3.60 & 0.55 & 0.013 & 0.36 & 0.43 \\
\hline
\end{tabular}

BCAA, branched-chain amino acid.

${ }^{*}$ For details of diets and procedures, see Table 1 and text.

† SED for diet $x$ insulin $\times$ stage of lactation. There were no significant $(P>0.05)$ interactions except where indicated.

$\ddagger$ Significant I $\times S$ interaction $(P<0.05)$.

\section{Discussion}

These data demonstrate that the simultaneous infusion of insulin and dextrose increased milk output but not milk protein content. Consequently, the simultaneous infusion of insulin and dextrose tended to increase milk protein yield, particularly during late lactation. As a result, there was an increase in piglet growth rate, primarily due to increased milk intake since there was no effect on the efficiency with which milk from sows infused with insulin and dextrose was used for growth by the piglets. It has generally been held that the ruminant, and indeed the sow, mammary gland is insensitive to insulin, particularly with respect to glucose uptake and lactose production (Hove, 1978; Laarveld et al. 1981, 1985). However, the studies on which this has been based have been relatively short in duration (hours), and euglycaemia has generally not been maintained. To partially address this, Mackle et al. $(2000 \mathrm{~b})$ conducted $4 \mathrm{~d}$ intramammary infusions of insulin

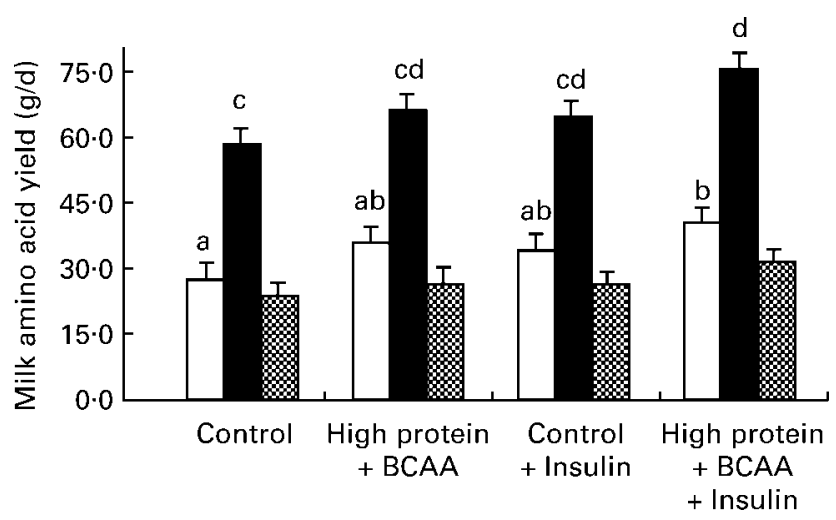

Fig. 4. Effect of control or high-protein + branched-chain amino acid (BCAA) lactation diets under basal conditions or during a simultaneous insulin and glucose infusion (Insulin) on milk BCAA yield. Values are means and SED for diet $X$ insulin. Values within an amino acid with different letters are significantly different $(P<0.05)$. $\square$, Valine; $\mathbf{\square}$, Leucine; 国, Isoleucine. that resulted in elevated milk insulin concentrations (25-fold) with no effect on systemic blood glucose concentrations. However, the intramammary insulin infusion had no effect on milk production or on milk fat and protein yields, further supporting the hypothesis that insulin does not appear directly to stimulate milk production or milk protein synthesis.

Increasing the protein level from 162 to $230 \mathrm{~g} / \mathrm{kg}$ while fortifying the diet with additional BCAA increased milk protein content and improved piglet growth. As a consequence, the milk from sows fed the higher-protein plus BCAA diet was used more efficiently than milk from sows fed what is generally considered to be a protein-adequate diet. These improvements in FCR presumably occur because of the increased protein:energy ratio in the milk from sows fed the fortified diets since increasing the dietary protein and BCAA level had no effect on milk yield. Whereas milk and protein yield can themselves increase with increasing lysine (protein) in the diet, particularly if energy intake is maximised (Tokach et al. 1992), the protein composition of milk still limits potential growth by $40 \%$. For example, King et al. (1993b) fed gilts diets ranging in protein content from 63 to $238 \mathrm{~g} / \mathrm{kg} \mathrm{CP}$ and found that only at the lower extremities were there any difference in the protein content of the milk. Certainly, increasing the dietary protein content above that fed in conventional rations $(168 \mathrm{~g} / \mathrm{kg})$ had no effect on milk protein content (King et al. 1993b). The major difference between our study and that of King et al. (1993b) was that we added supplemental BCAA. It may therefore be possible that BCAA limit milk production in conventional diets fed to lactating sows even when additional protein is provided above current recommendations.

Richert et al. (1996, 1997) have shown that increasing the valine and isoleucine content of sow diets with relatively low protein contents (approximately $145 \mathrm{~g} / \mathrm{kg} \mathrm{CP}$ ) will increase piglet litter growth. These authors also reported that increasing dietary isoleucine but not valine increased sow milk protein content (Richert et al. 1997). Interestingly, they also observed that increasing dietary valine, isoleucine and total BCAA resulted in 
Table 4. Effect of dietary protein, insulin infusion and stage of lactation on plasma amino acids $(\mu \mathrm{g} / \mathrm{ml})^{\star}$

\begin{tabular}{|c|c|c|c|c|c|c|c|c|c|c|c|c|}
\hline \multirow{2}{*}{$\begin{array}{l}\text { Diet (D) } \\
\text { Insulin (I) } \\
\text { Lactation stage (S) }\end{array}$} & \multicolumn{4}{|c|}{ Control } & \multicolumn{4}{|c|}{ High protein/BCAA } & \multirow{2}{*}{ SED† } & \multirow{2}{*}{\multicolumn{3}{|c|}{ Significance }} \\
\hline & \multicolumn{2}{|c|}{ Basal } & \multicolumn{2}{|c|}{ Insulin } & \multicolumn{2}{|c|}{ Basal } & \multicolumn{2}{|c|}{ Insulin } & & & & \\
\hline Alanine ${ }^{\star \star}$ & $79 \cdot 1$ & 93.4 & $85 \cdot 2$ & 94.4 & 60.5 & $46 \cdot 7$ & 41.5 & $60 \cdot 0$ & $13 \cdot 5$ & $<0.001$ & 0.91 & 0.021 \\
\hline Arginineł & $12 \cdot 4$ & $10 \cdot 3$ & 8.5 & $16 \cdot 5$ & $17 \cdot 7$ & $15 \cdot 0$ & 11.6 & $18 \cdot 4$ & 2.45 & 0.024 & 0.86 & 0.003 \\
\hline Aspartic acid $^{\star \star}$ & $6 \cdot 0$ & $10 \cdot 1$ & $9 \cdot 4$ & $6 \cdot 7$ & $7 \cdot 2$ & $7 \cdot 2$ & $5 \cdot 8$ & $7 \cdot 3$ & 1.51 & 0.25 & 0.37 & 0.046 \\
\hline Glutamic acid $\ddagger \mathbb{9}$ & $87 \cdot 7$ & 91.4 & $110 \cdot 6$ & 84.6 & $49 \cdot 3$ & $78 \cdot 7$ & $60 \cdot 5$ & $54 \cdot 6$ & $10 \cdot 6$ & $<0.001$ & 0.86 & 0.95 \\
\hline Glutamine $\|^{\star \star}$ & $57 \cdot 6$ & $109 \cdot 2$ & $87 \cdot 7$ & 59.8 & $67 \cdot 0$ & $28 \cdot 6$ & $31 \cdot 3$ & $52 \cdot 6$ & $13 \cdot 7$ & $<0.001$ & 0.096 & 0.72 \\
\hline Glycine $§ \rrbracket$ & $90 \cdot 4$ & 83.7 & $77 \cdot 1$ & $107 \cdot 2$ & $62 \cdot 2$ & $60 \cdot 0$ & $52 \cdot 8$ & $57 \cdot 7$ & 6.94 & $<0.001$ & 0.84 & 0.001 \\
\hline Histidineł & $24 \cdot 7$ & $30 \cdot 4$ & $29 \cdot 3$ & 25.5 & $28 \cdot 8$ & $31 \cdot 2$ & $28 \cdot 0$ & $28 \cdot 5$ & 2.32 & 0.25 & 0.26 & 0.16 \\
\hline Isoleucine§ & $13 \cdot 1$ & $9 \cdot 8$ & 8.9 & $14 \cdot 3$ & $20 \cdot 8$ & $26 \cdot 9$ & $21 \cdot 1$ & $22 \cdot 3$ & $2 \cdot 68$ & $<0.001$ & 0.056 & $<0.001$ \\
\hline Leucineף & 9.9 & 8.3 & $6 \cdot 7$ & 9.5 & 34.7 & $43 \cdot 1$ & 33.5 & $36 \cdot 7$ & 3.66 & $<0.001$ & 0.002 & $<0.001$ \\
\hline Lysineł" & $16 \cdot 4$ & $17 \cdot 9$ & $12 \cdot 4$ & $24 \cdot 0$ & $28 \cdot 0$ & $23 \cdot 4$ & $17 \cdot 0$ & $25 \cdot 4$ & 3.48 & 0.006 & 0.27 & 0.009 \\
\hline Methionine & 11.5 & $14 \cdot 1$ & $10 \cdot 2$ & $12 \cdot 1$ & $14 \cdot 3$ & $16 \cdot 4$ & 11.5 & $16 \cdot 1$ & 1.62 & 0.019 & 0.002 & $<0.001$ \\
\hline Serine & $12 \cdot 7$ & $14 \cdot 8$ & $11 \cdot 3$ & $15 \cdot 5$ & $13 \cdot 1$ & $12 \cdot 2$ & $9 \cdot 8$ & $14 \cdot 0$ & 1.40 & 0.16 & 0.16 & $<0.001$ \\
\hline Taurine & $9 \cdot 3$ & $11 \cdot 1$ & $11 \cdot 2$ & $10 \cdot 1$ & 8.9 & $10 \cdot 6$ & 8.4 & 9.7 & 1.45 & 0.23 & 0.85 & 0.11 \\
\hline Threonine $\ddagger$ & $25 \cdot 8$ & $25 \cdot 7$ & $16 \cdot 7$ & $30 \cdot 4$ & $26 \cdot 3$ & $27 \cdot 6$ & $20 \cdot 5$ & $28 \cdot 7$ & 3.60 & 0.65 & 0.003 & $<0.001$ \\
\hline Tyrosine ${ }^{\star \star}$ & 8.6 & $15 \cdot 2$ & $10 \cdot 6$ & 9.9 & 22.2 & $19 \cdot 1$ & 14.7 & 22.4 & $2 \cdot 15$ & $<0.001$ & 0.017 & 0.001 \\
\hline Valine $\S^{\star \star}$ & $66 \cdot 4$ & 48.4 & 44.9 & $77 \cdot 7$ & $82 \cdot 3$ & 97.4 & 79.5 & $84 \cdot 0$ & $9 \cdot 79$ & $<0.001$ & 0.23 & $<0.001$ \\
\hline
\end{tabular}

BCAA, branched-chain amino acid.

${ }^{*}$ For details of diets and procedures, see Table 1 and text.

†SED for diet $x$ insulin $x$ stage of lactation. There were no significant $(P>0.05)$ interactions except where indicated.

$\ddagger$ Significant I $\times S$ interaction $(P<0.05)$.

$\S$ Significant $\mathrm{D} \times \mathrm{S}$ interaction $(P<0.05)$

I Significant $\mathrm{D} \times \mathrm{I}$ interaction $(P<0.05)$.

${ }^{\star *}$ Significant $\mathrm{D} \times \mathrm{I} \times \mathrm{S}$ interaction $(P<0.05)$

an increased milk fat content. In the present work, there was no effect of BCAA on milk fat content $(P=0.91)$. This is presumably because sows in Richert and coworkers study (1997) mobilised more body fat than sows in the current study (although this was not measured). Increased milk fat is a common observation as mammals move into greater energy deficits (Bauman et al. 1989). On the other hand, in an earlier study, Richert et al. (1996) found that although increasing the valine content of a relatively low-protein $(143 \mathrm{~g} / \mathrm{kg} \mathrm{CP})$ basal diet increased litter growth, there was no effect on sow live weight or fat loss. The data of Richert et al. (1997) showed that when sows were fed relatively low levels of dietary protein, increasing the BCAA content alone of the diet could increase milk protein and fat content as well as increase piglet growth. Our study has shown that when sows are fed diets containing a higher basal level of protein $(162 \mathrm{~g} / \mathrm{kg} \mathrm{CP})$, increasing both the dietary protein and BCAA content can increase milk protein content and piglet growth without changing the fat content or milk yield.

Despite the absence of evidence to support a direct effect of insulin on milk protein synthesis, recent systemic simultaneous infusions of insulin and dextrose have been shown to increase milk protein content and yield in dairy cows (McGuire et al. 1995; Griinari et al. 1997; Leonard \& Block, 1997; Mackle et al. 1999, 2000a,b) and goats (Bequette et al. 2001). In their initial study, McGuire et al. (1995) observed that the circulating concentrations of amino acids, in particular BCAA, were markedly decreased, presumably because they were being preferentially oxidised or incorporated into milk proteins. Therefore, in a subsequent study, these authors supplied additional protein as an abomasal infusion of casein with and without insulin/dextrose infusions. Casein and insulin/dextrose alone increased milk protein yield by $10 \%$ and $4 \%$, respectively, whereas the combination treatment increased milk protein yield by $28 \%$ (Griinari et al. 1997). Although there were some increases in milk yield, the predominant response was an increase in milk protein content. Despite supplying additional protein as abomasal casein, the infusion of insulin and dextrose decreased the plasma concentrations of the BCAA valine, isoleucine and leucine by approximately $60 \%$. The plasma concentrations of the other essential amino acids decreased by an average of $25 \%$ (range $13-40 \%$ ).

Since it was likely that supplying additional BCAA may have stimulated milk protein yield even further, Mackle et al. $(2000 a, b)$ conducted a study in which they supplied abomasal casein and supplemental BCAA. Although they were able partially to ameliorate the insulin-stimulated decrease in plasma BCAA, the improvements in milk protein yield in response to insulin and dextrose infusion were of a similar magnitude to that observed by Griinari et al. (1997).

In the present study, the provision of supplemental amino acids, especially BCAA, ensured that there were sufficient amino acids so that milk protein production was not limited by amino acid or BCAA supply. Insulin infusion decreased the plasma concentrations of a few key amino acids, including isoleucine $(-6 \%)$, leucine $(-10 \%)$, methionine $(-11 \%)$, threonine $(-9 \%)$ and tyrosine $(-11 \%)$, although the magnitude of these decreases was relatively small and most pronounced in sows fed the additional protein and BCAA. The apparently small effect on plasma amino acids compared with dairy cows may be related to the low insulin infusion rate employed in the present study (see below). Certainly, higher doses of insulin decrease plasma amino acids in younger growing pigs (Wray-Cahen et al. 1997).

Reynolds and Rook (1977) found that the infusion of both insulin $(10$ or $100 \mathrm{U} / \mathrm{h})$ and glucose $(10$ or $20 \mathrm{~g} / \mathrm{h})$ alone increased milk protein concentrations or yield in lactating sows, but the 
mechanisms appeared to be different for the two. Also, these authors did not investigate the combination of insulin and glucose, the effects of which are interdependent. In particular, the insulin infusions resulted in sustained hypoglycaemia with a resultant decreased milk lactose yield and content.

The increase in milk yield observed during simultaneous insulin and dextrose infusions in the present study, in which glycaemia was maintained, may have been due to a stimulation of milk lactose secretion, which is in turn generally accepted as being the principal osmotic determinant of milk secretion. Therefore, insulin and/or dextrose infusions may increase milk protein yield through stimulating lactose secretion. In this context, Campbell et al. (1990) compared the inclusion of dietary dextrose compared with fructose in the diet of lactating sows and found that the former had a greater effect on plasma insulin, both pre- and post feeding, and increased litter growth rate in multiparous but not primiparous sows. Milk lactose content was higher in the milk of sows fed a diet containing $20 \%$ dextrose on day 18 but not 22 of lactation, whereas milk fat tended to be lower. Milk protein was not altered. It may therefore be possible to alter the insulin/glucose axis through including dextrose or sugar in the diet rather than by simultaneous infusion, as was the case in the present study.

The simultaneous infusion of dextrose and insulin caused a substantial reduction in fat mobilisation, as indicated by the reduction in plasma NEFA as occurs in ruminants and growing pigs (Dunshea et al. 1992, 1995; Petterson et al. 1993; McGuire et al. 1995). As a result, the milk fat content tended to be reduced in sows receiving the simultaneous infusions of insulin and dextrose. A reduction in milk fat content has also been oberved in dairy cows (McGuire et al. 1995; Griinari et al. 1997; Mackle et al. 1999) and goats (Bequette et al. 2001) receiving simultaneous infusions of insulin and dextrose. Therefore, manipulation of the insulin/glucose axis may be a method of reducing fat mobilisation and milk fat content in lactating sows. Reducing fat mobilisation would possibly aid in reducing the weaning-tomating interval as body fatness at weaning is negatively related to weaning-to-mating interval. In addition, sow's milk has a very high fat:protein ratio, which means that much of the energy in milk is not used for growth but is converted into body fat stores.

It is interesting to note that the effects of insulin that were observed in the present study in sows in peak lactation occurred with a relatively modest $(21 v .31 \mu \mathrm{U} / \mathrm{ml})$ proportional increment in plasma insulin that was still within the physiological range. Mid- to late-lactation dairy cows appear to have slightly higher plasma insulin concentrations than peak lactating sows (40-72 $\mu \mathrm{U} / \mathrm{ml}$; McGuire et al. 1995; Griinari et al. 1997; Mackle et al. 1999, 2000b), and most of the studies with dairy cows have involved higher insulin infusion rates than used here (11 v. $27 \mathrm{mU} / \mathrm{kg}$ per $\mathrm{h}$ ), resulting in proportionately greater increases in plasma insulin $(50 \%$ v. 500-1000\%). A preliminary study conducted before the current experiment found that a higher infusion rate than $11 \mathrm{mU} / \mathrm{kg}$ per $\mathrm{h}$ required a very high dextrose infusion rate to maintain glycaemia, with a resultant dramatic reduction (substitution) in feed intake. For example, during this preliminary study, insulin and dextrose rates infusion rates of $27 \mathrm{mU} / \mathrm{kg}$ per h and $2 \mathrm{~kg} / \mathrm{d}$ were associated with a $3 \mathrm{~kg} / \mathrm{d}$ decrease in feed intake.

Leury et al. (2003) conducted a study in early-lactation dairy cows and found that they had plasma insulin levels $(19 \mu \mathrm{U} / \mathrm{ml})$ similar to those observed here in early-lactation sows. These authors also had reduced feed intakes in their cows when infusions went beyond $2 \mathrm{~d}$ (BJ Leury, personal communication), and it is tempting to speculate that animals that are in early lactation and exhibit low endogenous insulin concentrations may be particularly sensitive to the effects of insulin on feed intake. Alternatively, it may be that pigs are much more sensitive to insulin than ruminants (Pethick \& Dunshea, 1996; Dunshea \& D'Souza, 2003). Dunshea \& D'Souza (2003) collated data from a number of in vitro studies and concluded that adipose tissue from pigs was much more sensitive to insulin than adipose tissue from ruminants. Pethick and Dunshea (1996) reached a similar conclusion based on whole-body glucose responses to exogenous insulin infusion.

In conclusion, these data demonstrate that increasing the dietary protein/BCAA content of the sow diet can increase milk protein secretion but not milk yield. A combined infusion of insulin and dextrose can increase milk, milk lactose and milk protein yields but not milk protein content. These effects are additive and translate to increased piglet growth. Further research is necessary to separate the dextrose and insulin effects and to determine the optimal way to modulate the insulin/dextrose/BCAA axis to increase milk protein yield and piglet growth on the farm.

\section{Acknowledgements}

The authors wish to thank Linda Morrish and Tamara Hauke for expert technical assistance in the conduct of the study, Maurice Kerr for conducting the amino acid analyses and Maree Cox for help in preparing the manuscript. This study was partially funded by Australian Pork Limited (formally the Pig Research and Development Corporation).

\section{References}

Atwood CS \& Hartmann PE (1992) Collection of fore and hind milk from the sow and changes in milk composition during suckling. $J$ Dairy Res 59, 287-298.

Auldist DE, Stevenson FL, Kerr MG, Eason PJ \& King RH (1997) Lysine requirements of pigs from 2 to $7 \mathrm{~kg}$ live weight. Anim Sci 65, 501-507.

Bauman DE, Dunshea FR, Boisclair YR, McGuire MA, Harris DM \& Houseknecht KL (1989) Regulation of nutrient partitioning: homeostasis, homeorhesis and exogenous somatotropin. Proceedings of the Seventh International Conference on Production Disease in Farm Animals, FA Kallfelz (ed.). Ithaca, NY: Cornell Univ Press, pp. 306-323.

Bequette BJ, Kyle CE, Crompton LA, Buchan V \& Hanigan MD (2001) Insulin regulates milk production and mammary gland and hind-leg amino acid fluxes and blood flow in lactating goats. J Dairy Sci 84, $241-255$.

Campbell WJ, Brendemuhl JH \& Bazer FW (1990) Effect of fructose consumption during lactation on sow and litter performance and sow plasma constituents. J Anim Sci 68, 1378-1388.

Dunshea FR (2003) Metabolic and endocrine changes around weaning. In Weaning the Pig, pp. 61-80 [JR Pluske, J Le Dividich and MVA Verstegen, editors]. Wageningen, The Netherlands: University of Wageningen Press.

Dunshea FR \& D'Souza DN (2003) Factors influencing fat deposition and metabolism in the pig. In Manipulating Pig Production IX, pp. 127-150 [J Paterson, editor]. Werribee, Australia: Australasian Pig Science Association.

Dunshea FR \& King RH (1995) Responses to homeostatic signals in ractopamine-treated pigs. Br J Nutr 73, 809-818.

Dunshea FR, Boisclair YR, Bauman DE \& Bell AW (1995) Effects of bovine somatotropin and insulin on whole-body and hindlimb glucose metabolism in the growing steer. J Anim Sci 73, 2263-2271. 
Dunshea FR, Harris DM, Bauman DE, Boyd RD \& Bell AW (1992) Effect of somatotropin on non-esterified fatty acid and glycerol metabolism in growing pigs. J Anim Sci 70, 132-140.

Glencross BD, Mullan BP, Tuckey RC \& Hartmann PE (1997) A simplification of the deuterium oxide dilution technique using FT-IR analysis of plasma, for estimating piglet milk intake. Aust J Agric Res 48, 1099-1104.

Griinari JM, McGuire MA, Dwyer DA, Bauman DE, Barbano DM \& House WA (1997) The role of insulin in the regulation of milk protein synthesis in dairy cows. J Dairy Sci 80, 2361-2371.

Hove K (1978) Maintenance of lactose secretion during acute insulin deficiency in lactating goats. Acta Physiolog Scandin 103, 173-179.

King RH, Rayner CJ \& Kerr M (1993a) A note on the amino acid composition of sow's milk. Anim Product 57, 500-502.

King RH, Toner MS, Dove H, Atwood CS \& Brown WG (1993b) The response of first-litter sows to dietary protein level during lactation. $J$ Anim Sci 71, 2457-2463.

Laarveld B, Christenson DA \& Brockman RP (1981) The effect of insulin on net metabolism of glucose and amino acids by the bovine mammary gland. Endocrinology 108, 2217-2221.

Laarveld B, Chaplin RK \& Brockman RP (1985) Effects of insulin on metabolism of acetate, beta-hydroxy butyrate and triglycerides by the bovine mammary gland. Comp Physiol Biochem 82B, 265-267.

Leonard M \& Block E (1997) Effects on nutrient and hormonal profile of long-term infusions of glucose or insulin plus glucose in cows treated with recombinant bovine somatotropin before peak milk yield. J Dairy Sci 80, 127-143.

Leury BJ, Baumgard LH, Block SS, Segoale N, Ehrhardt RA, Rhoads RP, Bauman DE, Bell AW \& Boisclair YR (2003) Effect of insulin and growth hormone on plasma leptin in periparturient dairy cows. Am J Physiol 285, R1107-R1115.

McGuire MA, Griinari JM, Dwyer DA \& Bauman DE (1995) Role of insulin in the regulation of mammary synthesis of fat and protein. J Dairy Sci 78, 816-824.

Mackle TR, Dwyer DA \& Bauman DE (2000a) Intramammary infusion of insulin or long R3 insulin-like growth factor-I did not increase milk protein yield in dairy cows. J Dairy Sci 83, 1740-1749.

Mackle TR, Dwyer DA, Ingvartsen KL, Chouinard PY, Lynch JM, Barbano DM \& Bauman DE (1999) Effects of insulin and amino acids on milk protein concentration and yield from dairy cows. J Dairy Sci $\mathbf{8 2}, 1512-1524$.

Mackle TR, Dwyer DA, Ingvartsen KL, Chouinard PY, Ross DA \& Bauman DE (2000b) Effects of insulin and postruminal supply of protein on use of amino acids by the mammary gland for milk protein synthesis. J Dairy Sci 83, 93-105.
Mellor DJ \& Cockburn F (1986) A comparison of energy metabolism in the new-born infant, piglet and lamb. $Q J$ Exp Physiol 71, 361-379.

Ostrowska E, Cross RF, Muralitharan M, Bauman DE \& Dunshea FR (2002) Effects of dietary fat and conjugated linoleic acid on plasma metabolite concentrations and metabolic responses to homeostatic signals in pigs. Br J Nutr 88, 625-634.

Pethick DW \& Dunshea FR (1996) The partitioning of fat in farm animals. Proc Nutr Soc Aust 20, 3-13.

Petterson JA, Dunshea FR, Ehrhardt RA \& Bell AW (1993) Pregnancy and undernutrition alter glucose metabolic responses to insulin in sheep. J Nutr 123, 1286-1295.

Prawirodigdo S, King RH, Dunkin AC \& Dove H (1990) Evaluation of techniques for estimating milk production by sows. 1. Deuterium oxide dilution method for estimating milk intake by piglets. AsianAustr J Anim Sci 3, 135-141.

Rayner C (1985) Protein hydrolysis of amino feeds for amino acid content. J Agric Food Chem 33, 725-731.

Reeds PJ \& Mersmann HJ (1991) Protein and energy requirements of animals treated with beta-adrenergic agonists: a discussion. J Anim Sci 69, 1532-1550.

Reynolds L \& Rook JAF (1977) Intravenous infusion of glucose and insulin in relation to milk secretion in the sow. Br J Nutr 37, 45-53.

Richert BT, Goodband RD, Tokach MD \& Nelssen JL (1997) Increasing valine, isoleucine, and total branched-chain amino acids for lactating sows. J Anim Sci 75, 2117-2128.

Richert BT, Tokach MD, Goodband RD, Nelssen JL, Pettigrew JE, Walker RD \& Johnston LJ (1996) Valine requirement of the high-producing lactating sow. J Anim Sci 74, 1307-1313.

Rutherfurd SM \& Moughan PJ (1998) The digestible amino acid composition of several milk proteins: application of a new bioassay. $J$ Dairy Sci 81, 909-917.

Tokach MD, Pettigrew JE, Crooker BA, Dial GD \& Sower AF (1992) Quantitative influence of lysine and energy intake on yield of milk components in the primiparous sow. J Anim Sci 70, 1864-1872.

Toner MS, King RH, Dunshea FR, Dove H \& Atwood CS (1996) The effect of exogenous somatotropin on lactation performance of firstlitter sows. J Anim Sci 74, 167-172.

Williams IH (1976) Nutrition of the young pig in relation to body composition. Thesis submitted for the degree of Doctor of Philosophy, University of Melbourne, Australia.

Wray-Cahen D, Beckett PR, Nguyen HV \& Davis TA (1997) Insulinstimulated amino acid utilization during glucose and amino acid clamps decreases with development. Am J Physiol (Endocrinol Metab) 273, E305-E314. 